RESEARCH ARTICLE

\title{
Holding Space and Engaging with Difference: Navigating the Personal Theories We Carry into Our Pedagogical Partnership Practices
}

\author{
*Christopher P. Ostrowdun, Werklund School of Education, University of Calgary, Canada \\ Rayna Friendly, Child and Adolescent Development, San José State University, USA
}

Kelly E. Matthews, Institute for Teaching and Learning Innovation, University of Queensland, Australia

Alise de Bie, Paul R. MacPherson Institute for Leadership, Innovation and Excellence in Teaching, McMaster University, Canada

Frits Roelofs, Faculty of Health and Social Studies, HAN University of Applied Sciences, the Netherlands

Contact: chris.ostrowdun@ucalgary.ca

\section{ABSTRACT}

Partnerships between students and faculty are increasingly established within higher education. Everyone's unique life story or background influences how they understand partnership praxis. Acknowledging individual understandings of student-faculty partnership matters because personal stories can influence how such partnerships form, function, and evolve. We, as students and faculty, share our individual theories of partnership to illuminate differing ways people can make sense of partnership as praxis. Using a reflective, autoethnographic research approach, we unpack two interdependent threads from our narratives: (a) holding space for how personal histories shape the experience of partnership and (b) engaging the messiness of partnership. To understand and nurture inclusive practices, we contend, means engaging the unique standpoints and social positions that both students and faculty bring into partnerships. Instead of attempting to collapse and converge different perspectives of partnership, we take pause to consider how these differences can enrich partnerships and be honoured throughout a partnership.

KEYWORDS

students as partners, partnership, narratives, stories, faculty-student partnership 
Quality relationships between students and faculty (i.e., educators) matter in higher education (Cureton \& Gravestock, 2018). Engaging in pedagogical partnerships, often discussed within the umbrella term Students as Partners (SaP), is fundamentally about learner-teacher relationships. Students can partner with faculty in and out of the classroom on an array of initiatives such as governance; curriculum enhancement; pedagogical practices; assessment design; discipline-based knowledge creation; institutional research, including the scholarship of teaching and learning (SoTL); and student experience (Cook-Sather, Bovill, \& Felten, 2014; Healey, Flint, \& Harrington, 2014). Research on Students as Partners (or research using similar terms) reveals a range of beneficial outcomes for both students and staff, such as improved engagement, learning, employability, and student-faculty relationships, along with a reduction in barriers inhibiting partnership practices including power, resistance, and logistics (Matthews, Mercer-Mapstone, et al., 2019). Partnerships are messy, sociocultural, and relational in nature where power and identity are always a factor (Matthews, Cook-Sather, et al., 2019).

In the spirit of partnership as a messy work-in-progress and out of a commitment to reflective writing and stories as legitimate scholarship (Cook-Sather, Abbot, \& Felten, 2019; Healey, Matthews, \& Cook-Sather, 2019), we join ongoing conversations about theorizations of partnership. We argue personal stories are sometimes lost in theorizations of partnership, and we encourage incorporating these unique stories and social locations (e.g., role, status, structure) as part of efforts to theorize partnership (e.g., Bovill \& Bulley, 2011; Cook-Sather et al., 2014; Healey et al., 2014; Matthews, 2017; Matthews, Cook-Sather, et al., 2019).

We dive into the diverse ways we come to, make sense of, and communicate about partnership praxis through an autoethnographic approach where we share our five individual theories of partnership. From these, we unpack two interwoven threads about engaging in student-faculty partnerships: (a) holding space for how personal histories shape partnership and (b) engaging the messiness of partnership. We close with implications for how practitioners can nurture partnership as ongoing, dynamic, and complex relationships. Specifically, by encouraging practitioners to listen and hear each other's perspectives - to hold space-and to consider how people from various social locations can partner in learning and teaching.

Diversity in our life stories and how we make sense of partnership may not surprise readers, as it would seem self-evident that making space for dialogue matters to any partnership, particularly in power-laden and hierarchical educational structures. Yet, research into student-faculty partnerships demonstrates students and faculty do not always do what is self-evident. For example, a student in an extracurricular partnership project remarked,

Sometimes communication was a bit of a struggle because everybody has their own way of formulating their opinions and everybody has their own perspectives. And at times we found that we were all formulating our opinions but we weren't actively listening to each other even though most of our opinions all had things in common. (Marquis, Black, \& Healey, 2017, p. 727) 
As a result, this student reported a loss of motivation and burn out (Marquis et al., 2017). This troubling result sounds the horn for more nuanced and attentive research that acknowledges the complex and multiple ways of being in partnership. As Marquis et al. (2017) argued, research into student-faculty partnership must move beyond the "celebratory" and "universalism" in scholarship and practice that masks variation.

While engaging in partnership can have an array of beneficial outcomes, literature indicates navigating relationships and the power dynamics inherent to them is the most widely reported inhibitor for partnership practices (Matthews, Mercer-Mapstone, et al., 2019). We also acknowledge the majority of research about pedagogical partnership has come from Western scholars in anglophone contexts and involves small numbers of students, and there are strong calls for more participation of equity-seeking students (Bindra et al., 2018; Green, 2019; Mercer-Mapstone et al., 2017; O'Shea, 2017). Such research is emerging, yet the lived realities are complicated (de Bie, Marquis, Cook-Sather, \& Luqueño, 2019; Cook-Sather, 2018). Yahlnaaw (2019), an Indigenous student reflecting on partnership experiences, explained,

I did not want to speak against those who were not students. . . I f felt that my voice was irrelevant as a student and as an Indigenous person - I was simply there to fulfil the diversity requirement . . . the dominance of colonial knowledges and pedagogical practices left me feeling I had little room to share my knowledge. (p. 7)

Much work remains to understand and nurture meaningful and inclusive learnerteacher partnership practices, which means asking tough questions about taken-for-granted dynamics that shape student-faculty interactions (Matthews, 2019). In this paper, we explore our diverse theories and stories of partnership in an attempt to hold space throughout a partnership to appreciate each other's ways of seeing the world instead of presuming a shared partnership identity that suggests a neat and easy process.

\section{CONNECTING, WRITING, AND REFLECTING TOGETHER: OUR RESEARCH APPROACH}

We embrace a reflective, shared auto-ethnographic research design that privileges subjectivity and reader-writer relationships. We draw on Merriam's (2009) notions of the socially constructed world where individuals hold differing perspectives shaped by worldviews and life experiences. First, we introduce ourselves in Table 1 and then share the story of the research and writing processes that led to our theorizations of partnership. Our research approach was emergent and fluid as we engaged in vibrant conversations, debates, analysis, and writing. We subscribed to an ethos of openness in designing and carrying out a research partnership.

Table 1. Who we are (in alphabetical order) and how we describe ourselves in our own words in relation to this work

\begin{tabular}{|l|l}
\hline Alise & When we initially started working together, I was a PhD student, as well as a
\end{tabular}

Ostrowdun, C.P., Friendly, R., Matthews, K.E., de Bie, A., \& Roelofs, F. (2020). Holding space and 


\begin{tabular}{|c|c|}
\hline & $\begin{array}{l}\text { university staff member and instructor. I have since graduated from being a } \\
\text { student. I've participated in a number of formal "Students as Partners" projects } \\
\text { since 2016-paid as a student on some, and as a staff member on others-at } \\
\text { McMaster University in Canada. I am also involved as a "service user" on } \\
\text { partnership projects with mental health care professionals, while in other } \\
\text { moments I am situated as a social work "professional" and instructor of social } \\
\text { work courses on disability/madness. Additionally, I have been both a community } \\
\text { organizer of Mad/disability peer support groups where I identify as a } \\
\text { peer/member, as well as a "partner" in social justice projects with equity-seeking } \\
\text { groups to which I do not belong. As a result of simultaneously occupying } \\
\text { numerous locations/positions within a range of partnerships (student-faculty, } \\
\text { service user-service provider, community-university, peer-based, cross-equity), } \\
\text { my relationships to partnership are rather complicated! }\end{array}$ \\
\hline Chris & $\begin{array}{l}\text { I am a PhD student (in Learning Sciences) at the University of Calgary, Canada. I } \\
\text { have participated in several student-faculty research partnerships within my } \\
\text { faculty and the university's institute for teaching and learning. My doctoral } \\
\text { research focuses on how educators perceive disability and inclusion, and how } \\
\text { their perceptions shape practice. I am also interested in how educators and } \\
\text { students can collaborate to better understand and improve teaching and } \\
\text { learning. I have been the Student Engagement Advisor for the SoTL Canada } \\
\text { Council and co-chair of the International Society for the Scholarship of Teaching } \\
\text { and Learning (ISSOTL) Student Engagement Interest Group. }\end{array}$ \\
\hline Frits & $\begin{array}{l}\text { At this moment, I am retired from being a senior staff member from the HAN } \\
\text { University of Applied Science in The Netherlands and also from being a teacher } \\
\text { and researcher in Dutch language and literature, after more than forty years in } \\
\text { secondary and higher education. I do miss young people around me at this } \\
\text { moment. They inspire me to do what I have to do in life! I have my own company } \\
\text { to coach and guide both professionals and students and pupils. I plan to write } \\
\text { articles or even a book about how students and professionals can work together } \\
\text { as real partners. In the past I have written a book about Emotional Intelligence in } \\
\text { Education, two books about how to study in higher education and a lot of articles } \\
\text { and columns about education, but almost all of them were in Dutch. Currently, I } \\
\text { am co-grandparenting six kids with fun and pride. }\end{array}$ \\
\hline Kelly & $\begin{array}{l}\text { I am now an associate professor working in a centralised teaching and learning } \\
\text { unit at the University of Queensland in Brisbane, Australia. I moved to Australia } \\
\text { from New Orleans, USA in 2006. I completed my PhD in } 2014 \text { in education while } \\
\text { working full-time. I co-parent two kids born in } 2013 \text { and } 2017 \text {. In } 2015 \text { I was } \\
\text { awarded an Australian Learning and Teaching Fellowship on the topic of engaging }\end{array}$ \\
\hline
\end{tabular}

Ostrowdun, C.P., Friendly, R., Matthews, K.E., de Bie, A., \& Roelofs, F. (2020). Holding space and 


\begin{tabular}{|l|l|}
\hline Rayna & $\begin{array}{l}\text { students as partners in learning and teaching. Since then I have spent a lot of } \\
\text { time engaging in, and thinking and writing about, Students as Partners in higher } \\
\text { education. }\end{array}$ \\
\hline $\begin{array}{l}\text { I completed my doctoral education in Developmental Psychology at McMaster } \\
\text { about student support, I completed a Postdoctoral position with our graduate } \\
\text { school and teaching institute, where I focused on providing students with training } \\
\text { to enhance their research, teaching, and professional development. I am } \\
\text { currently a Lecturer within the Child \& Adolescent Development department at } \\
\text { San José State University (SJSU) in California, USA. Here, I've been working with } \\
\text { SJSU's Peer Connections to partner with Student Peer Educators in my classroom. } \\
\text { These Peer Educators provide academic and resource support for students in } \\
\text { courses across the university that typically have lower success rates. }\end{array}$ \\
\hline
\end{tabular}

We-five co-authors from four countries, with differing experiences with studentfaculty partnerships-connected at the 2018 International Students as Partners Institute (ISaPI). This annual event brings together people to encourage "stretching participants' thinking about the possibilities for [student-faculty] partnership" (Marquis et al., 2019, p. 191). At ISaPI, we observed the many ways attendees made sense of partnership by drawing on their pedagogical stances and life histories to translate, often implicitly, theoretical frameworks of student-faculty partnership to discussions of practice. Kelly became curious about how the attendees' personal theories of partnership (compared to more objective or abstract theorizing) intersected with attempts to engage students and faculty as partners at their institutions. Kelly, thinking and reading about praxis - where theory (thinking) and practice (doing) are intertwined in constant conversation (Freire, 1970)-invited attendees, including undergraduate students, postgraduate students, academics/faculty, administrators, and professional staff to join a postISaPI collaboration exploring students as partners praxis.

In joining the collaboration, ISaPI participants were asked to share their personal theories of partnership, which were described as "the set of principles that inform and guide your practice of being in teaching and learning partnerships in higher education." The invitation was open-ended, with no expectation of reference to specific theoretical models. The four of us, Alise, Chris, Frits and Rayna, answered the call and joined Kelly. We note no undergraduate students or non-academic staff (beyond Alise who held multiple roles) elected to participate. The five of us come from different countries but our demographic makeup is similar and representative of ISaPI attendees: white, privileged, and from Western countries. We are an intergenerational collaboration ranging from early career to retirement with differing sexual identifications, mental health/disability backgrounds, and first languages.

We collaborated in a year-long series of conversations (via virtual meetings and emails), individual writing, and co-writing about student-faculty partnership. Our inquiry was centred on our collective self-the auto of autoethnography-"studying one's own experiences or those of 
one's community," where there is "an emphasis on the creative resources of writing, especially narrative, for generating, recording, and analyzing data" (Canagarajah, 2012, p. 260). Our approach privileged the narrative accounts of our personal theories of partnership, and our reflective processes supported and challenged us "to explore different realities and knowledges about learning and teaching" (Trahar, 2009, p. 1). Combining reflection and autoethnography invites personal and socially situated lived experiences to be the focus of inquiry (Ellis \& Bochner, 2000). Like Duarte's (2007) self-exploration as a SoTL practitioner, we are practitioners of partnership seeking to enhance our "sensitivity towards the knowledge gained in the process" (p. 2) of reflective analysis.

\section{OUR PERSONAL THEORIES OF STUDENT-FACULTY PARTNERSHIP}

After writing our personal theories, we realized our individual narratives were qualitatively different in tone, style, and content. Several of us initially tried a traditional approach to analysis of thematic grouping but felt the result was too sterile, too simple, and too void of our unique perspectives that brought us together. Our initial analysis was also asynchronous and individual, and it became apparent that none of us could authentically capture the perspectives of others without doing this work collaboratively rather than cooperatively (i.e., negotiating and developing ideas together rather than assembling ideas developed individually). Further discussions led us to keep the messiness of our personal theories and leverage them toward better understanding the complexities of student-faculty partnerships.

Our belief that people's experiences inform their personal theories of partnership inspired us to ask: What ideas are lost and privileged over others in the name of consensus? What personal histories of teaching, learning, partnership, and life are masked by neatly crafted lists of partnership principles or practices? Can we hold spaces for diverse or conflicting perspectives and still be considered partners? We argue partnership is relational work and should engage these questions thoughtfully, which we attempted in co-writing this paper. We share our theories in their raw form (presented below in alphabetical order) and reflect on how our ideas converge and diverge as we consider the implications for partnership praxis.

Alise de Bie, Postdoctoral Research Fellow (PhD student at the time of writing)

My theory focuses on how partnership approaches might contribute to social justiceboth at the micro level as well as campus-wide. I appreciate how partnerships invite different ways of relating to each other (relational justice), as opposed to only rearranging our infrastructure (structural justice), but I also want them to have impacts and effects beyond interpersonal relationships. At the same time, I'm really cautious about the notion of "partnership." The disability/psychiatric survivor communities I belong to have developed significant critiques of collaboration with more powerful others (de Bie 2020; de Bie \& Raaper, 2019).

Inspiration

Ostrowdun, C.P., Friendly, R., Matthews, K.E., de Bie, A., \& Roelofs, F. (2020). Holding space and 
My thinking towards and against partnership is informed by the academic disciplines of Mad(ness) and Disability Studies, Women's and Gender Studies, psychiatric survivor organizing, and the theoretical conceptualizations of epistemic injustice (Fricker, 2007), ethical loneliness (Stauffer, 2015), and psycho-emotional disablism (Reeve, 2012) that I developed through my doctoral work. I also think about how some of the proposed values/principles/goals of SaP (like trust, empathy, empowerment) have been theorized and troubled by survivors of trauma, feminists, and other critical theorists (de Bie, 2020). I value how theoretical frameworks can help me better understand-conceptually and practically-my experiences of and politics on partnership.

\section{Importance}

The university can be very isolating for people from equity-seeking groups, especially when we're engaged in equity-related studies (e.g., gender studies, disability studies) and have few colleagues working in our area. In response, I have had to search for colleagues across the institution. Often, folks interested in teaching, as part of that commitment, actually care about students, and engage in a lot of care labour to support them. Consequently, I've appreciated associating with these colleagues and SaP spaces that seek to challenge the university's usual culture of abandonment and neglect-even when I'm conflicted about partnership as a practice.

\section{Rayna Friendly, Lecturer}

My theory is that the student-faculty partnership can aim to be equitable (i.e., fair) but will never be equal (i.e., the same). The power dynamic between students and faculty is always present in some form, in the fact that students are given their grades, certifications, and reference letters by faculty. Thus, the status between the "partners" will never be truly equal. For this reason, during pedagogical partnerships, faculty have a responsibility to protect students in their relatively vulnerable positions, as well as to become a source of empowerment and mentorship for students.

\section{Inspiration}

As a teacher and researcher within the field of child development, I frequently consider ethical practices when working with vulnerable human populations. I've learned to question whether individuals are put into positions of potential harm (psychological, physical, confidentiality, etc.), and then restructure those situations in order to reduce the likelihood of such harms occurring. The same applies to situations when students and faculty form partnerships. One way my university reduces student vulnerability is to ensure faculty do not partner with students currently in their courses, to mitigate any potential grading biases by a student's faculty partner.

\section{Importance}

I believe a student-faculty partnership can be equitable where both parties can benefit from working together, each contributing in a "fair" way as agreed upon early in the 
partnership. I hope academic institutions will consider, ahead of time, the power dynamics that exist in these partnerships, as well as anticipate conflicts that may arise when designing or redesigning students-as-partners initiatives. This will help prevent potentially harmful outcomes for students (academically and professionally), while increasing chances for equitable and successful student-faculty partnerships.

\section{Kelly Matthews, Associate Professor (Higher Education)}

My theory is about relationships. For me, engaging with students as partners in higher education is about learner-teacher relationships. The spirit of challenging the status quo resonates with me. The SaP movement raises all kinds of questions about how students and academics (faculty) are positioned in relation to each other. How are they relating? The construct of partnership challenges traditional notions of how students and academics can interact and work together on learning and teaching. The values of partnership inform my practice. Empathy allows people to understand each other's standpoint. Being open to broader notions of who gets to contribute their expertise enables another way for students and academics to learning together. In doing so, assumptions about the "job of a student" and the "job of a teacher" are questioned, re-imagined, and re-shaped through dialogue.

\section{Inspiration}

As a student, I have rarely felt comfortable being myself in classrooms. As a teacher, I felt equally uncomfortable and constrained but in different ways. Growing up in New Orleans, I also took for granted my daily encounters with people from a range of standpoints and "diverse" groups, which felt comfortable and familiar in contrast to my daily life in Brisbane. Human relationships that foster questioning and challenge norms created possibilities that have transformed me far more than any classroom. I want those human relationships that engender an independence of thinking to be more common in higher education. SaP has given me the words to talk about what I think learning could be and the community to explore this thinking.

\section{Importance}

My theory of partnership gives me permission to be a different kind of academic. Through the broader SaP movement, I can connect with other people who share a commitment and ethos even though our practices might look different.

\section{Christopher Ostrowdun, PhD Candidate (Learning Sciences)}

My theory is rooted in how students and faculty do partnership, and what informs how partnership is done. The former is about what students and faculty bring to partnership (e.g., attitudes, expertise), what each does (e.g., shared goals, empathy, learning from each other), and what each leaves with (e.g., project outcomes, personal growth). For the latter, I draw on Clandinin's (2013) work on narrative inquiry, which I used in my Master's degree work, to see partnership as people coming alongside each other's lives. Partnerships are shaped by where 
they occur (physically and metaphorically), when they occur in the lives of each member (e.g., career stage, undergraduate/graduate student), and how each member engages in the relationship (e.g., social dynamics around power, intention, values).

\section{Inspiration}

In my experiences in SoTL partnerships with students and faculty, we sometimes reflected individually and collectively about our experiences of a partnership. We tried to make sense of what went well and our aspirations for future partnerships. Often we felt a partnership was greater than the sum of its parts and struggled to pinpoint what made a partnership tick. Our models and frameworks always felt incomplete, as if we were perpetually chasing just the right theory to capture it all.

\section{Importance}

With this theoretical framing I attempt to articulate three stages of partnershipcoming, doing, and going-and unpack three of the forces at play-place, time, and peoplethat inform what happens. I believe a humble, yet intentional, awareness of these forces can foster positive partnerships and an appreciation for the ebbs and flows that occur. Crucially, members of a partnership should actively discuss such forces and avoid assumptions about people's lives and experiences.

\section{Frits Roelofs, (Retired) Senior Staff Member}

My theory compares educational partnership with other partnerships, such as my lifepartner, a sparring-partner, or even a partner-in-crime. In every partnership you see three " $C$ "s. First, "contact": We have to spend time and energy to know each other as human persons. How do I drink my coffee, what is the colour of your eyes, and so on. The second, "contract": What do we have to do with/for each other? Raise our kids, start a business, study together? There are mutual goals. The third, "complementarity": After the first two Cs we can investigate where our differences are. How can I fill what my partner isn't capable to realize? How can we be reciprocal in a partnership? In education all over the world, people can only work and exist by the willingness of others to be part of the process of education. Imagine what it would look like if a teacher is teaching but no students are there. There is a great interdependency, and few people are aware of that.

\section{Inspiration}

When I look back to my history in education, both as a student and a teacher, the common thread is and was always the collaboration of all the people in education. Not only students and teachers, but also the collaboration of parents, managers, and others involved in education.

Importance 
By acknowledging and working with this interdependency, education could really change into a 21st-century-worthy and sustainable system where the main goal is learning, understood in all facets of the word, and not selecting the "right" people for the "right" goals.

\section{REFLECTIONS ON OUR PERSONAL THEORIES}

Our theories reflect a shared interest in partnership, while highlighting the various priorities and histories that influence how we understand partnership. We unpack two interdependent threads from our narratives: (a) holding space for how personal histories shape experiences of partnership and (b) engaging the messiness of partnership practices. We ask readers to consider how such factors can both complicate and enrich inclusive and meaningful student-faculty partnerships.

\section{Holding space for personal histories in partnership praxis}

Reflecting on our five personal theories of partnership shows how individual histories shape the ways people make sense of student-faculty partnership. Holding space is about listening to and hearing another person's perspectives and histories without passing judgement, and it avoids disempowering or devaluing another person's experiences (Floyd, 2016). Personal histories - the rich and intricate stories people bring, share, as well as develop together through lived experiences with others - frame the standpoints and expectations of individuals and institutions in learning communities (Mårtensson, Roxå, \& Stensaker, 2014). The different interpersonal and community relationships of our histories shape our dispositions, priorities, and the details of what we really mean by partnership. For example, Kelly plays with the paradox of valuing human relationships and connections while also valuing them as a way to engender independent thinking. Her feelings of discomfort in being herself growing up inspire Kelly to rethink relationships between students and faculty that question the unwritten rules of learner-teacher dynamics. In contrast, Alise writes about belonging to disability/psychiatric survivor communities and how the hesitation of "partnership" within these spaces has informed a critique of partnership as inherently good.

Kelly wants to engage students in partnership and foster relationships, but the historic wounds of partnering with more powerful others run deep and wide among members of particular communities, such as the disability/psychiatric survivor communities noted by Alise, which makes members of such communities cautious about partnerships. Yahlnaaw (2019), as an Indigenous person, experienced such a challenge first-hand when collaborating with some SoTL scholars and was told their Indigenous "approach to research was labelled 'alternative' because [they] do not believe in data collection in the Western tradition" (p. 7). To which Yahlnaaw remarked, "Indigenous knowledges were present long before colonial knowledges; therefore, if anything is to be labelled alternative, it is colonial knowledges" (p. 7). Such exchanges highlight the fragility of relationships and a need for both groups to have an equitable seat at the table. This means positioning students as empowered partners informed by their lived experiences and not as figurative advisors or commentators. It also means a mutual respect for troubled histories throughout a project, not just a lukewarm acknowledgement at the start. Trust between student and faculty partners is delicate, and a 
sense of caution may never dissolve. For example, holding space for Alise's kind, but firm, reminders of the complicated personal histories we bring to partnership helped make our writing more thoughtful and humble by challenging our assumptions about partnership praxis.

Several of us also tap into broader theoretical perspectives intertwined with lived experiences in how we understand partnership. Chris leverages narrative inquiry as a formal way to connect others' lived experiences with academia or to connect across disciplinary boundaries, where norms and practices may differ. Alise aligns their experiences with Mad (psychiatric), disability, and gender studies. Similarly, Rayna's training in child development and experience working with vulnerable populations inform a woven stance on protection and empowerment of students in such partnerships. Each theoretical lens a partner brings has specific histories and philosophical underpinnings, which are sometimes incompatible. For instance, Dollinger and Mercer-Mapstone's (2019) frank debate about neoliberal versus social justice lenses to student engagement showcases how seemingly opposing ideas can find points of connection, though not necessarily consensus or agreement. Explicitly creating spaces for conversations about individual perspectives can encourage partners to find ways to effectively engage in partnership despite-and sometimes because of-opposing ideas. However, some perspectives may be irreconcilable and forcing such a partnership could be damaging to those involved. Treading into unfamiliar territory requires time and space, yet they are crucial in better knowing how past experiences and familiarities with philosophical traditions shape future trajectories of partnership.

Each of our personal histories colour how we understand and engage in partnership. At the same time, when we and other scholars invoke models or principles of partnership (e.g., Bovill \& Bulley, 2011; Cook-Sather et al., 2014; Healey et al., 2014; Matthews, 2017) or derive new theorizations, it can be easy to lose such stories in an effort to generalize across contexts (Matthews, Cook-Sather, et al., 2019). Competing forces to find consensus, honour personal histories, and complete a project can strain a partnership. Such tension can be healthy if approached with a humble, thoughtful, and dialogic lens, while also respecting cases where irreconcilable differences indicate a partnership should not proceed.

\section{Engaging with the messiness of partnership}

Teaching and learning research is messy (Johnsen, Pacht, VanSlyck, \& Tsao, 2009), as are relational and lived pedagogical partnerships (Matthews, Cook-Sather, et al., 2019). People constantly straddle multiple contexts and relationships, and a student-faculty partnership may only be one small piece of a person's life. Each of us, in our own ways, encountered the messiness of partnership when writing our personal theories and reflecting upon them. While drafting this article-itself a partnership project-we wallowed in the messiness of how to connect, but also appreciate, our unique perspectives. In our conversations, Alise reminded us that plain "acceptance" of diversity can halt a person trying to meaningfully engage with differences - to hear and listen to each other. Moreover, some differences are irreconcilable and can challenge a partnership and attempts to find consensus or shared meaning. 
Some of us reflected on messiness in terms of power and identity. As one example, Alise's narrative troubles common presumptions of partnership as inherently a "good thing" and highlights the complexity of partnerships between students and faculty. For instance, how partnerships might be negotiated when members identify as belonging to a marginalized group alongside identifying as a student or faculty. Alise has seen negative repercussions for people belonging to disability/psychiatric survivor communities when they are part of educational collaborations that include substantial power disparities. Rayna emphasizes "faculty have a responsibility to protect students in their relatively vulnerable positions," which speaks to the messiness of power dynamics intersecting with identities. Faculty hold power but can also be vulnerable. Students and faculty share a responsibility of being empathetic and compassionate in understanding each other's identities and positions of power when engaging in partnership.

Some of us touched on the messiness of life intersecting with partnership. For instance, Chris resonates with the notion of coming alongside each other's lives (Clandinin, 2013) to acknowledge that the messiness of a partnership is couched within the messiness of life. He recalls how members of a partnership adapted to one member temporarily stepping away after having a child-a common life event, yet one not provisioned by many theoretical models of student-faculty partnership. We similarly experienced varying availability of time and energy as Alise defended their PhD and Rayna grappled with a heavy teaching load. These examples show the parallel tracks of students and faculty co-existing in shared spaces but experiencing them in diverse ways. Being busy is common but both sides may be unaware of the other's perspectives: students seldom get to peer behind the curtain of academic life and faculty may be years or decades removed from being a student. Partnerships need to acknowledge the complications of such differences and foster resilience to navigate a project's ebbs and flows.

Frits notes navigating and renegotiating traditional student-faculty norms is uncomfortable and emotional work, yet critical for meaningful partnerships (Hermsen, Kuiper, Roelofs, \& van Wijchen, 2017). By playing with the analogy of life-partners or sparring-partners, he emphasizes how the range of emotions in a partnership defines its richness. For Frits, being a pedagogical partner asks people to draw on their beliefs about partnership in the domain of daily life and imagine them in the domain of education. Frits' perspective reiterates how personal histories and experiences inside and outside the academy complicate partnerships but also give them meaning. Together, our narratives visualize the messiness and the richness of partnership that scholars encounter as they attempt to theorize partnership praxis (Matthews, Cook-Sather, et al., 2019).

\section{IMPLICATIONS FOR PARTNERSHIP PRACTICES}

The layers and levels of our theories vary, but a linking thread among us is relationships. Where we diverge is in how those relationships form, and what they mean for the practice and scholarship of partnership. For instance, as a student, Chris encourages faculty to use inclusive practices that do not presume students always want to be partners and recognize how students' personal lives could influence how they engage in partnership. In their roles as faculty, Rayna and Kelly point to their responsibilities to acknowledge power dynamics and

Ostrowdun, C.P., Friendly, R., Matthews, K.E., de Bie, A., \& Roelofs, F. (2020). Holding space and 
reconsider professional identities within traditional student-faculty relationships. Frits, now retired after a lifetime in the academy, reminds us to zoom out to the bigger picture of partnerships in life. He stresses interdependence between partners and getting to know each other as individuals rather than just by student or teacher roles. We relish this dissonance. We take pause.

We hope others take pause to consider diverse perspectives of partnership and how they are shaped by personal histories. Holding space for alternative experiences of studentfaculty partnership and personal histories can encourage people to resist quick movements toward consensus (e.g., progressing to project outcomes, publishing a paper; de Bie, 2020). Moreover, as researchers continue to theorize Students-as-Partners models to recognize that partnership is not a one-size-fits-all practice (Matthews, Cook-Sather, et al., 2019), we advocate people take time to identify narratives and perspectives that are at odds and consider ways to engage in partnership. As well, we encourage people to recognize when not to engage in partnership because of irreconcilable differences and the potential for harm. To facilitate more inclusive partnerships, we invite partners to iteratively revisit personal histories and perspectives to consider how these could be shaping a project and which perspectives are being privileged over others. In doing so, we are not seeking forced or performative selfdisclosure, as some people might feel uncomfortable disclosing different perspectives. In other words, sharing a personal history or conceptions of partnership should be an opportunity, not a requirement.

(Re)visiting personal histories before, during, and after partnership can be especially meaningful in moments of dissonance as partners reflect on their experiences and consider future trajectories. These are also moments to reimagine what partnerships are, and could be, as part of broader discussions about teaching and learning in higher education. Partnerships are chances to question the status-quo and push against dehumanizing and inequitable traditions of academia in how relations between students and faculty are conceived (Bindra et al., 2018; Cook-Sather \& Felten, 2017; Dwyer, 2018). We advocate for a partnership ethic that values human relationships by engaging the diverse life histories and stories that shape the unpredictable processes of learning, knowing, and being together in higher education.

\section{Limitations and future directions}

While this paper reflects an initial effort to think across the diverse perspectives we bring to this work, our social locations as white co-authors from Western countries no doubt limits how we theorize the impact of our personal histories on partnership. Contributions from non-dominant perspectives are needed to better understand and further theorize how personal histories inform work in partnership. Further work could explore more structured ways to hold space for personal histories and engage messiness within, or in addition to, existing partnership models. As well, research is needed to better understand how different perspectives and social locations of partners impact experiences and processes of partnership. In future work, we as authors, are curious about the perspectives of those from marginalized groups regarding the 
possibilities and limitations of partnership approaches, and the circumstances in which partnership might have negative consequences.

\section{CONCLUSION}

In the spirit of reflective practice (Schön, 1983) and praxis (Freire, 1970), we bring our narratives into conversation with personal histories and messiness as central constructs in partnership. In doing so, we tackle the necessary and generative tensions in how partnership praxis is theorized as complex, relational work (Matthews, Cook-Sather, et al., 2019). Instead of masking variation or striving for a tight conception of partnership, we deliberately keep our unique standpoints in view to inform how and why we engage in partnership practices. We urge for expansive thinking that enables practitioners to bring their own complicated stories and evolving theories to the growing movement of Students as Partners in an effort to enrich learning, teaching, and partnership work.

NOTE ON CONTRIBUTORS

Christopher Ostrowdun is a PhD Candidate in Learning Sciences at the University of Calgary in Canada.

Rayna Friendly is a Lecturer at San José State University in the United States.

Kelly Matthews is an Associate Professor in Higher Education at the University of Queensland in Australia.

Alise de Bie is a Postdoctoral Research Fellow at the Paul R. MacPherson Institute for Leadership, Innovation and Excellence in Teaching at McMaster University in Canada.

Frits Roelofs was a Senior Staff Member (retired) at the HAN University of Applied Sciences in the Netherlands.

\section{REFERENCES}

Bovill, C., \& Bulley, C. J. (2011). A model of active student participation in curriculum design: Exploring desirability and possibility. In C. Rust (Ed.), Global theories and local practices: Institutional, disciplinary and cultural variations (pp. 176-188). Oxford, UK: Oxford Brookes University.

Bindra, G., Easwaran, K., Firasta, L., Hirsch, M., Kapoor, A., Sosnowski, A., Stec-Marksman, T., \& Vatansever, G. (2018). Increasing representation and equity in students as partners 
initiatives. International Journal for Students as Partners, 2(2), 10-15.

https://doi.org/10.15173/ijsap.v2i2.3536

Canagarajah, A. S. (2012). Teacher development in a global profession: An autoethnography. Tesol Quarterly, 46(2), 258-279. https://doi.org/10.1002/tesq.18

Clandinin, D. J. (2013). Engaging in narrative inquiry. Walnut Creek, CA: Left Coast Press.

Cook-Sather, A. (2018). Listening to equity-seeking perspectives: How students' experiences of pedagogical partnership can inform wider discussions of student success. Higher Education Research \& Development, 37(5), 923-936.

Cook-Sather, A., Abbot, S., \& Felten, P. (2019). Legitimizing reflective writing in SoTL: "Dysfunctional illusions of rigor" revisited. Teaching \& Learning Inquiry, 7(2), 14-27. https://doi.org/10.20343/teachlearninqu.7.2.2

Cook-Sather, A., Bovill, C., \& Felten, P. (2014). Engaging students as partners in learning and teaching: A guide for faculty. San Francisco, CA: Jossey-Bass.

Cook-Sather, A., \& Felten, P. (2017). Ethics of academic leadership: Guiding learning and teaching. In F. Su \& M. Wood (Eds.), Cosmopolitan perspectives on academic leadership in higher education (pp. 175-191). London, UK: Bloomsbury.

Cureton, D., \& Gravestock, P. (2018) Supporting students' learning: The power of the studentteacher relationship. In M. Shah \& J. McKay (Eds.), Achieving equity and quality in higher education: Global perspectives in an era of widening participation (pp. 51-71). Cham, Switzerland: Palgrave Macmillan.

de Bie, A. (2020). Respectfully distrusting 'Students as Partners' practice in higher education: Applying a Mad politics of partnership. Teaching in Higher Education, 1-21

de Bie, A., \& Raaper, R. (2019, March 29). Troubling the idea of partnership [Blog post]. Retrieved from https://macblog.mcmaster.ca/summer-institute/2019/03/29/troublingthe-idea-of-partnership/

de Bie, A., Marquis, E., Cook-Sather, A., \& Luqueño, L. P. (2019). Valuing knowledge(s) and cultivating confidence: Contributions of student-faculty pedagogical partnerships to epistemic justice. In J. Hoffman, P. Blessinger, \& M. Makhanya (Eds.), Strategies for fostering inclusive classrooms in higher education: International perspectives on equity and inclusion (pp. 35-48). https://doi.org/10.1108/S2055-364120190000016004

Dollinger, M., \& Mercer-Mapstone, L. (2019). What's in a name? Unpacking students' roles in higher education through neoliberal and social justice lenses. Teaching \& Learning Inquiry, 7(2), 73-89. https://doi.org/10.20343/teachlearninqu.7.2.5

Duarte, F. P. (2007). Using autoethnography in the scholarship of teaching and learning: Reflective practice from 'the other side of the mirror.' International Journal for the Scholarship of Teaching and Learning, 1(2), 21. https://doi.org/10.20429/ijsotl.2007.010221

Dwyer, A. (2018). Toward the formation of genuine partnership spaces. International Journal for Students as Partners, 2(1), 11-15. https://doi.org/10.15173/ijsap.v2i1.3503 
Ellis, C., \& Bochner, A. (2000). Autoethnography, personal narrative, reflexivity: Researcher as subject. In N. Denzin \& Y. Lincoln (Eds.), Sage handbook of qualitative research (2nd ed., pp. 733-768). Thousand Oaks, CA: Sage.

Floyd, A. H. L. (2016). Holding space: A reflection about teaching a class on forgiveness. Jesuit Higher Education: A Journal, 5(2).

Freire, P. (1970). Pedagogy of the oppressed. New York, NY: Herder and Herder.

Fricker, M. (2007). Epistemic injustice: Power and the ethics of knowing. Oxford, UK: Oxford University Press.

Green, W. (2019). Stretching the cultural-linguistic boundaries of "Students as Partners." International Journal for Students as Partners, 3(1), 84-88. https://doi.org/10.15173/ijsap.v3i1.3791

Healey, M., Flint, A., \& Harrington, K. (2014). Engagement through partnership: Students as partners in learning and teaching in higher education. Retrieved from https://www.heacademy.ac.uk/engagement-through-partnership-students-partnerslearning-and-teaching-higher-education

Healey, M., Matthews, K. E., \& Cook-Sather, A. (2019). Writing scholarship of teaching and learning articles for peer-reviewed journals. Teaching \& Learning Inquiry, 7(2), 28-50. https://doi.org/10.20343/teachlearninqu.7.2.3

Hermsen, T., Kuiper, T., Roelofs, F., \& van Wijchen, J. (2017). Without emotions, never a partnership! International Journal for Students as Partners, 1(2). https://doi.org/10.15173/ijsap.v1i2.3228

Johnsen, H. L., Pacht, M., VanSlyck, P. E., \& Tsao, T. M. (2009). The messy teaching conversation: Toward a model of collegial reflection, exchange, and scholarship on classroom problems. Teaching English in the Two-Year College, 37(2).

Marquis, E., Black, C., \& Healey, M. (2017). Responding to the challenges of student-staff partnership: The reflections of participants at an international summer institute. Teaching in Higher Education, 22(6), 720-735. https://doi.org/10.1080/13562517.2017.1289510

Marquis, E., Guitman, R., Black, C., Healey, M., Matthews, K. E., \& Dvorakova, L. S. (2019). Growing partnership communities: What experiences of an international institute suggest about developing student-staff partnership in higher education. Innovations in Education and Teaching International, 56(2), 184-194. https://doi.org/10.1080/14703297.2018.1424012

Mårtensson, K., Roxå, T., \& Stensaker, B. (2014). From quality assurance to quality practices: An investigation of strong microcultures in teaching and learning. Studies in Higher Education, 39(4), 534-545. https://doi.org/10.1080/03075079.2012.709493

Matthews, K. (2017). Five propositions for genuine students as partners practice. International Journal for Students as Partners, 1(2). https://doi.org/10.15173/ijsap.v1i2.3315

Matthews, K. E. (2019). Rethinking the problem of faculty resistance to engaging with students as partners in learning and teaching in higher education. International Journal for the 
Scholarship of Teaching and Learning, 13(2), 2.

https://doi.org/10.20429/ijsotl.2019.130202

Matthews, K. E., Cook-Sather, A., Acai, A., Dvorakova, S. L., Felten, P., Marquis, E., \& MercerMapstone, L. (2019). Toward theories of partnership praxis: An analysis of interpretive framing in literature on students as partners in teaching and learning. Higher Education Research \& Development, 38(2), 280-293. https://doi.org/10.1080/07294360.2018.1530199

Matthews, K. E., Mercer-Mapstone, L., Dvorakova, S. L., Acai, A., Cook-Sather, A., Felten, P., Healey, M., Healey, R., \& Marquis, E. (2019). Enhancing outcomes and reducing inhibitors to the engagement of students and staff in learning and teaching partnerships: Implications for academic development. International Journal for Academic Development, 24(3), 246-259. https://doi.org/10.1080/1360144x.2018.1545233

Mercer-Mapstone, L., Dvorakova, S. L., Matthews, K. E., Abbot, S., Cheng, B., Felten, P., Knorr, K., Marquis, E., Shammas, R., \& Swaim, K. (2017). A systematic literature review of students as partners in higher education. International Journal for Students as Partners, 1(1), 1-23. https://doi.org/10.15173/ijsap.v1i1.3119

Merriam, S. (2009). Qualitative research: A guide to design and implementation. San Francisco, CA: Jossey-Bass.

O'Shea, S. (2018). Equity and students as partners: The importance of inclusive relationships. International Journal for Students as Partners, 2(2), 16-20. https://doi.org/10.15173/ijsap.v2i2.3628

Reeve, D. (2012). Psycho-emotional disablism: The missing link? In N. Watson, A. Roulstone, \& C. Thomas (Eds.), Routledge handbook of disability studies (pp. 78-92). London, UK: Routledge.

Schön, D. A. (1983). The reflective practitioner: How professionals think in action. New York, NY: Basic Books.

Stauffer, J. (2015). Ethical loneliness: The injustice of not being heard. New York, NY: Columbia University Press.

Trahar, S. (2009). Beyond the story itself: Narrative inquiry and autoethnography in intercultural research in higher education. Forum Qualitative Sozialforschung / Forum: Qualitative Social Research, 10(1), 30. https://doi.org/10.17169/fqs-10.1.1218

Yahlnaaw. (2019). T'aats'iigang-Stuffing a jar full. International Journal for Students as Partners, 3(2), 6-10. https://doi.org/10.15173/ijsap.v3i2.4081 